\title{
ANALISIS GANGGUAN PENDENGARAN PADA PENYELAM DI DANAU TONDANO DESA WATUMEA KECAMATAN ERIS KABUPATEN MINAHASA PROVINSI SULAWESI UTARA 2014
}

\author{
${ }^{1}$ Rahayu D. C. Ruslam \\ ${ }^{2}$ Jimmy F. Rumampuk \\ ${ }^{2}$ Vennetia R. Danes
}

\author{
${ }^{1}$ Kandidat Skripsi Bagian Fisika Kedokteran Universitas Sam Ratulangi Manado \\ ${ }^{2}$ Bagian Fisika Kedokteran Universitas Sam Ratulangi Manado \\ Email: ewhiedruslam@gmail.com
}

\begin{abstract}
Hearing disorder is the change in the level of hearing which resulted in difficulties in carrying out a normal life, usually in terms of understanding speech. This study aimed to analyze hearing disorder that may arise among the divers in Watumea Eris, North Sulawesi, in 2014. This was an analytical study using a cross sectional approach. Population consisted of all divers in Lake Tondano during 2014. Samples were 20 people, obtained by using a purposive sampling technique based on the needs of researcher. The results of the analysis in the form of age $(p=0.157)$, education $(p=0.662)$, tenure $(p=0.850)$, history of the disease $(p$ $=0.897)$, diving frequency $(\mathrm{p}=0.577)$, using protective equipment $(\mathrm{p}=0.075)$, diving depth $(p=0.526)$, and duration of diving $(p=0.964)$. Conclusion: There was no correlation of diving and hearing disorder among divers at lake Tondano Watumea Eris village district of Minahasa North Sulawesi Province during 2014.
\end{abstract}

Keywords: hearing disorder, divers

\begin{abstract}
Abstrak: Gangguan pendengaran adalah perubahan tingkat pendengaran yangmengakibatkan kesulitan dalam melaksanakan kehidupan normal, biasanya dalamhal memahami pembicaraan. Penelitian ini bertujuan untuk menganalisis gangguan pendengaran yang dapat timbul pada penyelam di desa Watumea Kecamatan Eris Provinsi Sulawesi Utara 2014. Penelitian ini merupakan jenis analitik dengan pendekatan potong lintang. Populasi ialah semua penyelam di danau Tondano selama 2014. Jumlah sampel 20 orang, diperoleh dengan teknik purposive sampling berdasarkan kebutuhan penelitian. Hasil penelitian memperlihatkan nilai p untuk umur $\mathrm{p}=0,157$, pendidikan $\mathrm{p}=0,662$, masa kerja $\mathrm{p}=0,850$, riwayat penyakit $\mathrm{p}=0,897$, frekuensi menyelam $\mathrm{p}=0,577$, menggunakan alat pelindung $\mathrm{p}=0,075$, kedalaman menyelam $\mathrm{p}=0,526$, dan lama menyelam $p=0,964$. Simpulan: Tidak terdapat hubungan menyelam dengan gangguan pendengaran pada penyelam di danau Tondano desa Watumea Kecamatan Eris Kabupaten Minahasa Provinsi Sulawesi Utara selama 2014.
\end{abstract}

Kata kunci: gangguan pendengaran, penyelam

Gangguan pendengaran merupakan masalah yang umum dialami setiap orang dari waktu ke waktu. Gangguan pendengaran didefinisikan sebagai pengurangan dalam kemampuan seseorang untuk membedakan suara. Gangguan pendengaran sering terjadi ketika menaiki pesawat terbang atau mendaki gunung, pekerja pabrik dan juga para nelayan. Di dunia, menurut perkiraan WHO, 80\% orang yang mengalami masalah gangguan pendengaran tinggal di negara berkembang. Pada tahun 1995 terdapat 120 juta penderita gangguan pendengaran di seluruh dunia. Jumlah tersebut mengalami peningkatan yang sangat 
bermakna pada tahun 2001 menjadi 250 juta orang. Pada tahun 2005, WHO memperkirakan terdapat 278 juta orang menderita gangguan pendengaran, 75 - 140 juta diantaranya terdapat di Asia Tenggara.

Jumlah orang di seluruh dunia dengan semua tingkat gangguan pendengaran meningkat terutama disebabkan meningkatnya populasi global dan usia harapan hidup. Persentase prevalensi gangguan pendengaran pada populasi penduduk secara umum bervariasi dari minimal 4,2\% di Indonesia hingga 9\% di Sri Lanka, 13,3\% di Thailand dan 16,6\% di Nepal. Berdasarkan angka-angka diatas, terdapat lebih daripada 100 juta orang yang menderita masalah ketulian dan gangguan pendengaran di kawasan Asia Timur. ${ }^{1}$

Indonesia adalah negara kepulauan memiliki sekitar 17.508 pulau besar dan kecil ( \pm 6000 pulau tidak berpenghuni) yang menyebar disekitar garis Khatulistiwa yang mempunyai iklim tropis. Total wilayah $1.919 .440 \mathrm{~km}^{2}$ total presentase wilayah perairan $4,85 \%$. Luas perairan laut Indonesia diperkirakan sebesar 5.8 juta km2 dengan garis pantai terpanjang di dunia sebesar $81.000 \mathrm{~km}$, gugusan pulau- pulau sebanyak 17.508, dan diperkirakan memiliki potensi produksi ikan sebanyak 6.26 juta ton pertahun. ${ }^{1,2}$

Kegiatan penyelaman yang melibatkan masyarakat nelayan telah dilakukan sejak dahulu, walaupun tidak ada catatan khusus mengenai hal ini, namun sebagai negara dengan wilayah perairan yang sangat luas tentu telah memanfaatkan sumber daya laut secara intensif. Kegiatan penyelaman itu sendiri seharusnya dilihat sebagai suatu kegiatan mencari nafkah dengan lingkungan kerja penyelaman. $^{2}$

Nelayan penyelam tradisional dan penyelam tradisional banyak terdapat di wilayah Indonesia terutama di daerah pesisir dan kepulauan, yang kebanyakan belum pernah mengikuti pendidikan atau pelatihan dalam hal penyelaman secara formal karena keterbatasan dana dan jangkauan jarak ke tempat pelatihan. Para nelayan penyelam tradisional umumnya hanya melakukan pekerjaan secara turuntemurun atau mengikuti yang lain, serta tanpa dibekali ilmu kesehatan dan keselamatan penyelaman yang memadai. Pada umumnya penyelaman yang dilakukan nelayan penyelam tradisional dan penyelam tradisional adalah penyelaman tahan napas dan penyelaman dengan mengunakan suplai udara dari permukaan laut atau danau yang dialirkan melalui kompresor udara. ${ }^{3}$

Kegiatan penyelaman memiliki prosedur standar, namun beberapa penyelam tradisional tidak mengetahuinya. Nelayan penyelam tradisional pantai Puger selama ini menggunakan teknik tradisional yang belum sesuai dengan kesehatan dan keselamatan liळg்|Kndgmesia,gangguanp kerja khususnya peraturan penyelaman berulang. Pada nelayan penyelam dipulau Karimun Jawa tahun 2007 menyebutkan barotrauma yang paling banyak terjadi adalah gangguan pendengaran 43,2\%, gangguan saluran hidung 16,9\% dan gangguan paru 14,9\%. Data yang dikumpulkan Dit Sepim Kesma Depkes sampai dengan tahun 2008, dari 1.026 penyelam ditemukan $93,9 \%$ penyelam pernah menderita gejala awal penyakit penyelaman, yaitu sebanyak 29,8\% menderita nyeri sendi $39,5 \%$ menderita gangguan pendengaran dan 10,3\% menderita kelumpuhan, yang sebagian besar diantaranya adalah penyelam tradisional.

Kasus kejadian gangguan pendengaran akibat penyelaman belum terdata dengan jelas di daerah Provinsi Sulawesi utara khususnya kasus kejadian gangguan pendengaran akibat penyelaman di danau.Begitu pula kelainan pernapasan bagian atas, prevalensi terbesar didapatkan pada para penyelam (nelayan yang mencari ikan dengan menyelam). ${ }^{4}$

Desa Watumea Kecamatan Eris merupakan salah satu desa di kabupaten Minahasa Propinsi Sulawesi Utara. Secara geografis berbatasan dengan kecamatan Tondano Timur di sebelah utara, kecamatan Kombi di sebelah timur, 
kecamatan Kakas di sebelah selatan, dan danau Tondano di sebelah barat. Selain bekerja sebagai petani, peternak, wirausaha dan PNS sebagian besar masyarakat desa mencari nafkah sebagai nelayan penyelam tradisional. Hal ini dikarenakan terdapat danau besar yang berada di daerah desa Watumea. ${ }^{5}$ Dari

latar belakang tersebut maka peneliti tertarik untuk melakukan penelitian tentang analisis gangguan pendengaran pada penyelam di danau desa Watumea Kecamatan Eris Kabupaten Tondano Provinsi Sulawesi Utara 2014.

\section{METODE PENELITIAN}

Penelitian ini termasuk jenis penelitian analitik dengan pendekatan potong lintang dimana dicari hubungan menyelam dan gangguan pendengaran pada penyelam. Dilakukan pada bulan NovemberDesember 2014 di desa Watumea Kecamatan Eris Kabupaten Minahasa Provinsi Sulawasi Utara. Populasi dalam penelitian ini adalah semua penyelam di danau Tondano desa Watumea Kecamatan Eris Kabupaten Minahasa Provinsi Sulawesi Utara. Pengambilan sampel di tentukan dengan menggunakan metode purposive sampling dan besar jumlah sampel adalah 20 orang.

\section{HASIL PENELITIAN}

Penelitian ini dilaksanakan selama satu bulan yakni bulan November 2014. Lokasinya terletak di Desa Watumea Kecamatan Eris Kabupaten Minahasa. Responden pada penelitian ini yaitu penyelam tradisional yang berjumlah 20 orang.

Karakterisitik responden dalam penelitian ini meliputi umur dan pendidikan (Tabel 1).

Tabel 1. Distribusi Karakteristik Responden Menurut Usia

\begin{tabular}{ccc}
\hline Umur & $\mathrm{n}$ & $\%$ \\
\hline$\leq 40$ tahun & 6 & 30 \\
$>40$ tahun & 14 & 70 \\
\hline Total & 20 & 100 \\
\hline
\end{tabular}

Tabel 1 menunjukkan bahwa responden yang berusia lebih dari 40 tahun berjumlah lebih banyak yaitu 14 orang dengan persentase (70\%) dibandingkan dengan usia dibawah 40 tahun yang berjumlah 6 orang dengan persentase (30\%).

Tabel 2. Distribusi Karakteristik Responden Menurut Pendidikan

\begin{tabular}{ccc}
\hline Tingkat Pendidikan & $\mathrm{n}$ & $\%$ \\
\hline SD & 5 & 25 \\
SMP & 3 & 15 \\
SMA & 12 & 60 \\
\hline Total & 20 & 100 \\
\hline
\end{tabular}

Tabel 2 menunjukkan bahwa tingkat pendidikan responden terbanyak ialah SMA yaitu 12 orang dengan persentase (60\%) sedangkan yang paling sedikit SMP yaitu 3 orang dengan persentase (15\%) diikuti dengan tingkat pendidikan SD yaitu 5 orang dengan persentase (25\%).

Tabel 3. Distribusi Responden Menurut Masa Kerja

\begin{tabular}{ccc}
\hline Masa Kerja & $\mathrm{n}$ & $\%$ \\
\hline$\leq 20$ tahun & 15 & 75 \\
$>20$ tahun & 5 & 25 \\
\hline Total & 20 & 100 \\
\hline
\end{tabular}

Tabel 3 menunjukkan bahwa masa kerja nelayan penyelam terbanyak ialah kurang dari atau sama dengan 20 tahun yaitu 15 orang, dengan persentase (75\%) sedangkan yang paling sedikit yaitu masa kerja lebih dari 20 tahun yaitu 5 orang dengan persentase (25\%).

Tabel 4. Distribusi Responden Menurut Riwayat Penyakit

\begin{tabular}{ccc}
\hline Riwayat Penyakit & $\mathrm{n}$ & $\%$ \\
\hline Pernah & 17 & 85 \\
Tidak pernah & 3 & 15 \\
\hline Total & 20 & 100 \\
\hline
\end{tabular}

Tabel 4 menunjukkan bahwa nelayan yang pernah memiliki riwayat penyakit berjumlah lebih banyak yaitu 17 orang dengan presentase $85 \%$, sedangkan nelayan 
yang tidak pernah memiliki riwayat penyakit sebelumnya berjumlah lebih sedikit yaitu sebanyak 3 orang dengan presentase $15 \%$.

Tabel 5. Distribusi Responden Menurut Frekuensi Menyelam

\begin{tabular}{ccc}
\hline Frekuensi Menyelam & $\mathrm{n}$ & $\%$ \\
\hline Sering & 13 & 65 \\
Jarang & 7 & 35 \\
\hline Total & 20 & 100 \\
\hline
\end{tabular}

Tabel 5 menunjukan bahwa sebanyak 13 orang nelayan penyelam dengan persentase (65\%) sering melakukan penyelaman sedangkan sebanyak 7 orang nelayan penyelam dengan persentase (35\%) jarang melakukan penyelaman.

Tabel 6. Distribusi Responden Menurut Ketaatan Menggunakan Alat Pelindung Dalam Menyelam

\begin{tabular}{ccc}
\hline $\begin{array}{c}\text { Menggunakan Alat } \\
\text { Pelindung }\end{array}$ & $\mathrm{n}$ & $\%$ \\
\hline Tidak Taat & 18 & 90 \\
Taat & 2 & 10 \\
\hline Total & 20 & 100 \\
\hline
\end{tabular}

Tabel 6 menunjukan bahwa 18 orang nelayan penyelam dengan persentase (90\%) tidak taat menggunakan alat pelindung sedangkan 2 orang lainnya dengan persentase $(10 \%)$ taat menggunakan alat pelindung.

Tabel 7. Distribusi Responden Menurut Kedalaman Menyelam

\begin{tabular}{ccc}
\hline Kedalam Menyelam & $\mathrm{n}$ & $\%$ \\
\hline$\leq 10$ meter & 19 & 95 \\
$>10$ meter & 1 & 5 \\
\hline Total & 20 & 100 \\
\hline
\end{tabular}

Tabel 7 menunjukan bahwa 19 orang dengan persentase (95\%) menyelam dengan kedalaman menyelam kurang dari atau sama dengan 10 meter sedangkan terdapat 1 orang nelayan penyelam dengan persentase (5\%) menyelam dengan kedalaman menyelam lebih dari 10 meter.
Tabel 8. Distribusi Responden Menurut Lama Menyelam

\begin{tabular}{ccc}
\hline Lama Menyelam & $\mathrm{n}$ & $\%$ \\
\hline$\leq 30$ menit & 7 & 35 \\
$>30$ menit & 13 & 65 \\
\hline Total & 20 & 100 \\
\hline
\end{tabular}

Tabel 8 menunjukan bahwa 13 orang dengan persentase (65\%) dengan lama menyelam lebih dari 30 menit dan terdapat 7 orang nelayan penyelam dengan persentase (35\%) yang lama menyelamnya kurang dari atau sama dengan 30 menit.

\section{BAHASAN}

Dari data penelitian yang diperoleh, usia rata-rata nelayan penyelam yang semuanya berjenis kelamin laki-laki adalah lebih dari atau sama dengan 40 tahun. Untuk melihat hubungan antara umur dengan gangguan pendengaran, maka umur dikelompokkan menjadi 2 kelompok, yaitu kelompok umur $\leq 40$ tahun dan umur $>40$ tahun. Hasil pengamatan di lapangan menunjukkan bahwa nelayan penyelam yang berusia lebih dari 40 tahun lebih banyak yaitu berjumlah 14 orang, dengan persentase (70\%) dibandingkan dengan usia dibawah 40 tahun yang berjumlah 6 orang dengan persentase (30\%).

Hasil analisis bivariat dengan chisquare memperlihatkan bahwa faktor resiko umur tidak ada hubungan yang bermakna terhadap gangguan pendengaran pada nelayan penyelam, nilai $\mathrm{p}=0,157(\mathrm{p}>0,05)$. Hasil penelitian ini serupa dengan hasil penelitian Ekawati yang memperlihatkan bahwa tidak ada hubungan umur dengan gangguan pendengaran pada nelayan penyelam tradisional, nilai $\mathrm{p}=0,060$ $(\mathrm{p}>0,05)$.

Berdasarkan hasil penelitian ini terdapat 3 orang yang mengalami tuli ringan dan 6 orang tuli sedang pada kelompok umur lebih atau sama dengan 40 tahun sedangkan hanya terdapat 2 orang yang mengalami tuli ringan pada kelompok umur kurang dari 40 tahun. Hasil penelitian ini juga sejalan dengan hasil penelitian 
Mahmoud et al. yang menemukan nelayan penyelam yang berusia lebih dari 40 tahun memiliki resiko 4 kali lebih banyak dibandingkan usia yang lebih muda, dan salah satu resikonya ialah gangguan pendengaran. ${ }^{6,7}$

Pendidikan merupakan salah satu faktor penentu setiap orang dalam berperilaku. Semakin tinggi pendidikan seseorang maka semakin baik juga orang tersebut untuk menjaga hidupnya dalam hal ini kesehatannya. Dari data penelitian yang diperoleh, nelayan penyelam yang banyak mengalami gangguan pendengaran adalah nelayan yang memiliki tingkat pendidikan SMA yaitu 2 tuli ringan dan 3 tuli sedang sedangkan yang paling sedikit mengalami gangguan pendengaran yaitu nelayan yang memiliki tingkat pendidikan SMP yaitu 1 tuli ringan dan 1 tuli sedang dan diikuti oleh nelayan dengan tingkat pendidikan SD yaitu 2 tuli ringan dan 2 tuli sedang. ${ }^{2}$

Untuk melihat hubungan antara umur dengan gangguan pendengaran, maka umur dikelompokkan menjadi 2 kelompok, yaitu masa kerja $\leq 20$ tahun dan umur $>20$ tahun. Hasil analisis bivariat dengan chisquare, $\alpha=0,05$ diperoleh $\mathrm{p}=0,850$ ( $>0,05)$ menunjukan bahwa lamanya masa kerja tidak berhubungan dengan gangguan pendengaran nelayan penyelam. Hasil penelitian ini sejalan dengan penelitian Mahmoud et al. yang memperoleh $\mathrm{p}=$ 0,409. Hasil penelitian ini juga sejalan dengan hasil penelitian Ekawati yang mendapatkan $\mathrm{p}=1,000$. $^{6,7}$

Tabel 9. Hasil Analisis Bivariat

\begin{tabular}{|c|c|c|c|c|c|c|c|}
\hline \multirow[t]{2}{*}{ Penyelam } & \multicolumn{4}{|c|}{ Gangguan Pendengaran } & \multirow{2}{*}{$\begin{array}{c}\text { Total } \\
\text { (n) }\end{array}$} & \multirow[t]{2}{*}{ Nilai p } & \multirow[t]{2}{*}{ Kesimpulan } \\
\hline & Normal & T. Ringan & T. Sedang & T. Berat & & & \\
\hline $\begin{array}{l}\text { Umur } \\
\leq 40 \text { Tahun } \\
>40 \text { Tahun } \\
\end{array}$ & $\begin{array}{l}4(66,7 \%) \\
5(35,7 \%) \\
\end{array}$ & $\begin{array}{l}2(33,3 \%) \\
3(21,4 \%) \\
\end{array}$ & $\begin{array}{l}0(0,0 \%) \\
6(42,9 \%)\end{array}$ & $\begin{array}{l}0(0,0 \%) \\
0(0,0 \%)\end{array}$ & $\begin{array}{l}6 \\
14 \\
\end{array}$ & 0,157 & $\begin{array}{l}\text { Tidak Ada } \\
\text { Hubungan }\end{array}$ \\
\hline $\begin{array}{l}\text { Pendidikan } \\
\text { SD } \\
\text { SMP } \\
\text { SMA } \\
\end{array}$ & $\begin{array}{l}1(20,0 \%) \\
1(33.3 \%) \\
7(58,3 \%)\end{array}$ & $\begin{array}{l}2(40,0 \%) \\
1(33.3 \%) \\
2(16,7 \%)\end{array}$ & $\begin{array}{l}2(40,0 \%) \\
1(33.3 \%) \\
3(25,0 \%) \\
\end{array}$ & $\begin{array}{l}0(0,0 \%) \\
0(0,0 \%) \\
0(0,0 \%)\end{array}$ & $\begin{array}{l}5 \\
3 \\
12 \\
\end{array}$ & 0,662 & $\begin{array}{l}\text { Tidak Ada } \\
\text { Hubungan }\end{array}$ \\
\hline $\begin{array}{l}\text { Masa Kerja } \\
\leq 20 \text { Tahun } \\
>20 \text { Tahun }\end{array}$ & $\begin{array}{l}7(46,7 \%) \\
2(40,0 \%)\end{array}$ & $\begin{array}{l}4(26,7 \%) \\
1(20,0 \%)\end{array}$ & $\begin{array}{l}4(26,7 \%) \\
2(40,0 \%)\end{array}$ & $\begin{array}{l}0(0,0 \%) \\
0(0,0 \%)\end{array}$ & $\begin{array}{l}15 \\
5\end{array}$ & 0,850 & $\begin{array}{l}\text { Tidak Ada } \\
\text { Hubungan }\end{array}$ \\
\hline $\begin{array}{l}\text { Riwayat } \\
\text { Penyakit } \\
\text { Pernah } \\
\text { Tidak Pernah }\end{array}$ & $\begin{array}{l}8(47,1 \%) \\
1(33,3 \%)\end{array}$ & $\begin{array}{l}4(23,5 \%) \\
1(33,3 \%)\end{array}$ & $\begin{array}{l}5(29,4 \%) \\
1(33,3 \%)\end{array}$ & $\begin{array}{l}0(0,0 \%) \\
0(0,0 \%)\end{array}$ & $\begin{array}{l}17 \\
3\end{array}$ & 0,897 & $\begin{array}{l}\text { Tidak Ada } \\
\text { Hubungan }\end{array}$ \\
\hline $\begin{array}{l}\text { Frekuensi } \\
\text { Menyelam } \\
\text { Jarang } \\
\text { Sering } \\
\end{array}$ & $\begin{array}{l}3(42,9 \%) \\
6(46,2 \%) \\
\end{array}$ & $\begin{array}{l}1(14,3 \%) \\
4(30,8 \%) \\
\end{array}$ & $\begin{array}{l}3(42,9 \%) \\
3(23,1 \%) \\
\end{array}$ & $\begin{array}{l}0(0,0 \%) \\
0(0,0 \%)\end{array}$ & $\begin{array}{l}7 \\
13 \\
\end{array}$ & 0,577 & $\begin{array}{l}\text { Tidak Ada } \\
\text { Hubungan }\end{array}$ \\
\hline $\begin{array}{l}\text { Menggunakan } \\
\text { Alat Pelindung } \\
\text { TidakTaat } \\
\text { Taat } \\
\end{array}$ & $\begin{array}{l}9(50,0 \%) \\
0(0,0 \%) \\
\end{array}$ & $\begin{array}{l}5(27,8 \%) \\
0(0,0 \%) \\
\end{array}$ & $\begin{array}{l}4(22,2 \%) \\
2(100,0 \%)\end{array}$ & $\begin{array}{l}0(0,0 \%) \\
0(0,0 \%)\end{array}$ & $\begin{array}{l}18 \\
2 \\
\end{array}$ & 0,075 & $\begin{array}{l}\text { Tidak Ada } \\
\text { Hubungan }\end{array}$ \\
\hline $\begin{array}{l}\text { Menggunakan } \\
\text { Alat Pelindung* } \\
\text { TidakTaat } \\
\text { Taat } \\
\end{array}$ & $\begin{array}{l}8(53,3 \%) \\
1(20,0 \%)\end{array}$ & $\begin{array}{l}5(33,3 \%) \\
0(0,0 \%)\end{array}$ & $\begin{array}{l}2(13,3 \%) \\
4(80,0 \%)\end{array}$ & $\begin{array}{l}0(0,0 \%) \\
0(0,0 \%)\end{array}$ & $\begin{array}{l}15 \\
5\end{array}$ & 0,017 & $\begin{array}{l}\text { Ada } \\
\text { Hubungan }\end{array}$ \\
\hline $\begin{array}{l}\text { Kedalaman } \\
\text { Menyelam } \\
>10 \text { meter } \\
\leq 10 \text { meter }\end{array}$ & $\begin{array}{l}1(100,0 \%) \\
8(42,1 \%)\end{array}$ & $\begin{array}{l}0(0,0 \%) \\
5(26,3 \%) \\
\end{array}$ & $\begin{array}{l}0(0,0 \%) \\
6(31,6 \%) \\
\end{array}$ & $\begin{array}{l}0(0,0 \%) \\
0(0,0 \%)\end{array}$ & $\begin{array}{l}1 \\
19 \\
\end{array}$ & 0,526 & $\begin{array}{l}\text { Tidak Ada } \\
\text { Hubungan }\end{array}$ \\
\hline $\begin{array}{l}\text { Lama Menyelam } \\
>30 \text { menit } \\
\leq 30 \text { menit }\end{array}$ & $\begin{array}{l}6(46,2 \%) \\
3(42,9 \%)\end{array}$ & $\begin{array}{l}3(23,1 \%) \\
2(28,6 \%)\end{array}$ & $\begin{array}{l}4(30,8 \%) \\
2(28,6 \%)\end{array}$ & $\begin{array}{l}0(0,0 \%) \\
0(0,0 \%)\end{array}$ & $\begin{array}{l}13 \\
7\end{array}$ & 0,964 & $\begin{array}{l}\text { Tidak Ada } \\
\text { Hubungan }\end{array}$ \\
\hline
\end{tabular}

Keterangan:

* = data perbandingan 
Bedasarkan hasil penelitian ini nelayan penyelam dengan masa kerjanya $\leq 20$ tahun (40\%) lebih banyak mengalami gangguan pendengaran yaitu 4 orang yang mengalami tuli ringan dan 4 orang tuli sedang sedangkan pada nelayan penyelam yang masa kerjanya $>20$ tahun (15\%) hanya terdapat 1 tuli ringan dan 2 tuli sedang. Hasil penelitian ini tidak jauh berbeda dengan hasil penelitian Mahmoud et al. yang menemukan $56,4 \%$ nelayan penyelam yang masa kerjanya $\leq 20$ tahun sedangkan $43,6 \%$ nelayan penyelam yang masa kerjanya $>20$ tahun. Masa kerja dapat menentukan lamanya paparan seseorang terhadap faktor risiko, semakin lama paparan berdasarkan masa kerja akan semakin besar kemungkinan seseorang mendapatkan faktor risiko tersebut dalam hal ini gangguan pendengaran. Dari hasil penelitian yang dilakukan oleh Darrly (2005) pada penyelam tradisional di Minahasa Utara menunjukkan bahwa gangguan pendengaran banyak terdapat pada penyelam tradisional dengan masa kerja diatas 6 tahun, namun secara teori belum ada yang membuktikan pengaruhnya masa kerja terhadap gangguan pendengaran. $^{8,9}$

Untuk melihat hubungan antara riwayat penyakit dengan gangguan pendengaran, maka riwayat penyakit dikelompokkan menjadi 2 kelompok, yaitu pernah dan tidak pernah. Hasil analisis bivariat dengan chi-square, $\alpha=0,05$ diperoleh $\mathrm{p}=0,897(\mathrm{p}>0,05)$ menunjukkan bahwa riwayat penyakit nelayan penyelam tidak berhubungan dengan gangguan pendengaran. Dengan demikian faktor riwayat penyakit tidak berpengaruh terhadap gangguan pendengaran, sehingga perlu dilihat faktor risiko lainnya, antara lain: umur, pendidikan, masa kerja, frekuensi menyelam, kedalaman menyelam dan lama menyelam nelayan penyelam.

Untuk melihat hubungan antara Frekuensi dengan gangguan pendengaran, maka frekuensi menyelam dikelompokkan menjadi 2 kelompok, yaitu sering dan jarang. Hasil analisis bivariat dengan chi- square, $\alpha=0,05$ diperoleh $p=0,577$ ( $>0,05)$ menunjukkan bahwa frekuensi menyelam nelayan penyelam tidak berhubungan dengan gangguan pendengaran. Hasil penelitian ini tidak sejalan dengan hasil penelitian Ekawati yang menemukan adanya hubungan frekuensi penyelaman dengan Gangguan pendengaran dengan nilai $\mathrm{p}=0,011$ $(p<0,05)$. Hal ini dapat disebabkan karena kedalaman dasar danau di tempat lokasi penelitian hanya mencapai 12 meter sehingga nelayan tidak harus mencapai dasar danau untuk mencari ikan. ${ }^{7}$

Untuk melihat hubungan antara menggunakan alat pelindung dengan gangguan pendengaran, maka dikelompokkan menjadi 2 kelompok, yaitu taat dan tidak taat. Hasil analisis bivariat dengan chi-square, $\alpha=0,05$ diperoleh $\mathrm{p}=0,075$ ( $p>0,05)$ menunjukan bahwa menggunakan alat pelindung nelayan penyelam tidak berhubungan dengan gangguan pendengaran. Hasil penelitian ini tidak sejalan dengan hasil penelitian Ekawati yang menemukan adanya hubungan antara ketaatan penggunaan alat pelindung dengan gangguan pendengaran dengan nilai $\mathrm{p}=0,011 \quad(\mathrm{p}<0,05) . \quad$ Dalam penelitian Ekawati ditemukan jumlah responden yang tidak taat dalam menggunakan alat pelindung lebih besar dari pada yang taat yaitu $(68,9 \%)$ yang tidak taat dan $(31,1 \%)$ yang taat.

Hasil perbandingan dalam penelitian ini antara jumlah responden yang tidak taat dalam menggunakan alat pelindung lebih besar dari pada yang taat yaitu (75\%) yang tidak taat dan (25\%) yang taat. Analisis penggunaan alat pelindung saat menyelam menunjukan bahwa menggunakan alat pelindung nelayan penyelam berhubungan dengan gangguan pendengaran. Hasil analisa bivariat dengan chi-square, $\alpha=0,05$ diperoleh $\mathrm{p}=0,017 \quad(\mathrm{p}<0,05)$. Hasil penelitian ini serupa dengan hasil penelitian El-Saadawy et all yang menemukan adanya hubungan penggunaan alat pelindung dengan gangguan pendengaran dengan nilai $\mathrm{p}<0,001$. Hal ini dapat terjadi karena 
responden yang tidak taat dalam menggunakan alat pelindung menyelam akan kesulitan dalam bernapas dibandingkan yang taat hal ini dapat berakibat pada peningkatan tekanan pada daerah telingga sehingga berdampak buruk pada membran timpani dan tulang-tulang pendengaran. Kondisi ini apabila dibiarkan akan berdampak pada gangguan pendengaran.

Untuk melihat hubungan antara kedalaman menyelam dengan gangguan pendengaran, maka dikelompokkan menjadi 2 kelompok, yaitu masa kerja $\leq 10$ meter dan $>10$ meter. Hasil analisis bivariat dengan chi-square, $\alpha=0,05$ diperoleh $\mathrm{p}=0,897(\mathrm{p}>0,05)$ menunjukan bahwa kedalaman menyelam nelayan penyelam tidak berhubungan dengan gangguan pendengaran. Hasil penelitian ini sejalan dengan hasil penelitian Arief et al. yang memperoleh nilai $\mathrm{p}=0,350(\mathrm{p}>0,05)$ yang artinya tidak ada pengaruh kedalaman terhadap gangguan pendengaran. Hasil penelitian ini sejalan dengan hasil penelitian Alaa et al. yang menemukan nilai $p=1,767 \quad(p>0,05)$, walaupun perbedaan penelitian yang dilakukan oleh Alaa et al. menggunakan kelompok penyelaman yang $\leq 20 \mathrm{~m}$ dan $>20$ meter. Hasil penelitian ini juga sesuai dengan penelitian Budiono yang menyebutkan bahwa kedalaman menyelam tidak ada hubungan dengan gangguan pendengaran. Hal ini juga dapat disebabkan karena nelayan penyelam, menyelam tidak terlalu dalam. Sesuai dengan hasil wawancara pada nelayan penyelam banyak penyelam yang menyatakan mereka menyelam $<5$ meter. ${ }^{3,10}$

Hasil penelitian ini berbeda dengan hasil penelitian yang dilakukan oleh Kartono tahun 2007 pad penyelam di kabupaten Jepara, menunjukkan bahwa faktor risiko yang paling dominan untuk kejadian gangguan pendengaran dalah faktor kedalaman penyelaman $(\mathrm{OR}=0,55)$. Setiap penurunan kedalaman penyelaman 10 meter, risiko penyelam mengalami gangguan pendengaran sebesar 0,55 kali. $^{9}$ Untuk melihat hubungan antara lama menyelam dengan gangguan pendengaran, dikelompokkan menjadi 2 kelompok, yaitu masa kerja $\leq 30$ meter dan umur $>30$ meter.

Dari hasil penelitian menunjukan bahwa nelayan penyelam dengan waktu menyelam > 30 menit $65 \%$, sedangkan nelayan penyelam dengan lama waktu penyelaman $\leq 30$ menit $35 \%$. Hasil analisa bivariat dengan chi-square, $\alpha=0,05$ diperoleh $p=0,964$ ( $p>0,05)$ menunjukan bahwa lama menyelam nelayan penyelam tidak berhubungan dengan gangguan pendengaran. Hasil penelitian ini sejalan dengan hasil penelitian Tuti Ekawati yang memperoleh nilai $p=0,965(p>0,05)$ yang artinya tidak ada pengaruh kedalaman terhadap gangguan pendengaran. Peranan lama menyelam pada penyelam dalam mempengaruhi kesehatan dalam hal ini gangguan pendengaran di tentukan oleh perubahan faktor etiologi karena adanya perubahan tekanan udara yang tinggi. ${ }^{7}$

\section{SIMPULAN}

Berdasarkan hasil analisis dapat disimpulkan tidak adanya hubungan menyelam dengan gangguan pendengaran pada penyelam di danau Tondano desa Watumea Kecamatan Eris Kabupaten Minahasa Provinsi Sulawesi Utara.

\section{SARAN}

1. Perlu dilakukan penyuluhan kesehatan untuk meminimalkan resiko terjadinya gangguan pendengaran pada nelayan penyelam.

2. Diperlukan suatu penelitian lanjut dengan jumlah responden yang lebih banyak untuk mengetahui seberapa besar pengaruh menyelam pada nelayan penyelam terhadap kejadian gangguan pendengaran.

3. Perlu dilakukan penelitian perbandingan gangguan pendengaran antara penyelam di danau dan laut sehingga dapat dijadikan bahan untuk memperkaya informasi dan pengetahuan di bidang kesehatan.

4. Perlu dilakukan penelitian yang lebih lanjut tentang pengaruh menyelam 
terhadap dampak-dampak kesehatan yang lainnya.

5. Dilakukan penelitian lebih lanjut mengenai cara pencegahan dan pengobatan ketulian pada penyelam.

\section{DAFTAR PUSTAKA}

1. Yathavan S. Gambaran Etiologi Gangguan Pendengaran Di RSUP H. Adam Malik Medan Dari Periode 1 Januari - 31 Desember 2009. Universitas Sumatera Utara. Medan, 2010.

2. Abshor A. Pengaruh Barotrauma Auris Terhadap Gangguan Pendengaran Pada Nelayan Penyelam Di Kecamatan Puger Kabupaten Jember. Universitas Jember Jember, 2008.

3. Prasetyo A.T, Soemantri BJ, Lukmantya. Pengaruh Kedalaman Dan Lama Menyelam Terhadap Ambang-Dengar Penyelam Tradisional Dengan Barotruma Telinga. ORLI Vol. 42 No. 2 Tahun 2012. Universitas Brawijaya. Malang, 2012.

4. DKP: Indonesia Timur Butuh 2 Ribu Dokter Kelautan.Republika Online. Available at:

http://www.republika.co.id/berita/bre aking-news/nasional/09/08/24/71209dkp-indonesia-timur-butuh-2-ribudokter-kelautan. Diakses tanggal 01 Oktober 2014.

5. Kodoati G, Waleleng POV, Lainawa J, Mokoagow DR. Analisis Potensi Sumberdaya Alam, Tenaga Kerja,
Pertanian dan Perkebunan Terhadap Pengembangan Peternakan Sapi Potong Di Kecamatan Eris Kabupaten Minahasa. Jurnal Zootek Vol. 34 (Edisi Khusus): 15-26 (Mei 2014). Universitas Sam Ratulangi. Manado, 2014.

6. Ekawati T. Analisis Faktor Risiko Barotrauma Membran Timpani Pada Neyalan Tradisional Di Kecamatan Semarang Utara Kota Semarang. Universitas Diponegoro Semarang. 2005

7. El-Saadawy ME, Soliman NE, El-Tayeb IM, Hammouda MA. Some Occupational Health Hazards Among Fishermen In Alexandria City. Gaziantep Med J 2014;20(1):71-78

8. Kristianto W. Gambaran Gangguan Pendengaran Pada Penyelam TNI Angkatan Laut. Universitas Indonesia. Depok, 2012.

9. Paskarini I, Tualeka AR, Ardianto DY, Dwiyanti E. Kecelakaan Dan Gangguan Kesehatan Penyelam Tradisional Dan Faktor-Faktor Yang Mempengaruhinya Di Kabupaten Seram, Maluku. http://portalgaruda.org/article.17835\& 1095.Pdf

10.Abid AH, Al-Asadi JN, Habib OS. Hearing Loss in Iraqi Divers. The Medical Journal Of Bahsrah University Vol 24, No 1 \& 2, 2006. 